\title{
SUBORDINATION OF PURCHASE-MONEY SECURITY
}

Typically, when an individual purchases a large amount of raw acreage for the purpose of subdivision and resale, he has neither the entire purchase price nor the capital for the construction. Therefore the buyer will usually operate on long term credit. This credit often takes the form of purchase-money security in favor of the seller, and a construction loan secured by a deed of trust on the property in favor of a third party lender, normally an institutional lender. ${ }^{I}$

A problem arises because the commercial lender is required by statute to hold the first deed of trust on the property. ${ }^{2}$ However, the purchase money security is usually the senior lien. ${ }^{3}$ Therefore it is necessary, in order to obtain the construction loan from the institutional lender, that the buyer obtain the promise of the seller to waive his statutory priority and accept the junior lien on the property. This waiver is "subordination." 4

There are several reasons why the seller is willing to subordinate. He doubtless receives additional consideration, usually in the form of a higher purchase price. Further, it is assumed that the actual value of the construction lien will increase only as the property under development enjoys a corresponding increase in value, due to the accompanying progress in the construction. This assumption is not always correct. ${ }^{5}$ The risk nevertheless is a significant one.

1 For discussion of financing commercial and residential developments, see CALTF. C.E.B., Calmornia Land Security AND Development 489-560 (1960); Balter, Tracts and Taxes, 31 Cat. S.B.J. 110 (1956); Storke \& Sears, Subdivision Financing, 28 Rocky MT. L. Rev. 549 (1956).

2 Commercial lenders are closely regulated by the Financial Code. It permits all institutions to loan on the security of real property only if they hold the first lien. See CaL. FIN. CoDE $\S \S 1413$ (d) (savings banks), 7102 (a) (savings and loan associations), 1560 (trust companies); 36 OPS. ATT'y Gen. CaL. 188 (1960).

3 Purchase money security given "at the time of . . . conveyance, has priority over all other liens created against the purchaser . . . " CAL. Crv. CODE $\$ 2898$. This provision is subject to the recording acts.

4 While "subordination" is the accepted term for the intentional alteration of priorities, it is not yet separately indexed for research purposes. The most productive headings for further research are: "Real Property-Security Instruments," "Liens," "Priority," "Finance," "Mortgages," and "Vendor and Purchaser."

This Comment is confined to a discussion of the subordination of purchase money security to construction loan security. The term itself is not so limited. A lease executed after a deed of trust is inferior to the security, and is subject to the foreclosure. Security-First Nat'l Bank v. Marxen, 28 Cal. App. 2d 282, 82 P.2d 727 (1938). Often the lessee will obtain an agreement from the henholder subordinating the hen to the lease, thereby protecting him from foreclosure. Bank of America v. Hirsch Mer. Co., 64 Cal. App. 2d 175, 148 P.2d 110 (1944). The considerations in this type of agreement are distinct from those which form the substance of this Comment. The lessee and lienholder are parties to the subordination agreement, whereas the construction lender is not. The agreement is between the buyer and seller of the property. Whatever rights the construction lender takes are as a third party beneficiary.

The term is not unique to real property. It is also found in the terminology of corporate financing, where the right to receive payment of a certain indebtedness is "subordinated" to the prior payment of the same debtor. The semor debt must be paid in full before payment nuay be nuade on the subordinated debt and retained by the subordinating creditor. For discussion, see Calligar, Subordination Agreements, 70 YALE L.J. 376 (1961).

5 The buyer may, unless restricted by the agreement, encumber real property with a loan of a high percentage of the property's appraised value. For example, a savings and loan association may issue amortized loans upon the security of improved real property in an amount not in excess of $70 \%$ of the appraised value. CAL. FIN. CODE $\$ 7152$. If any loan 
If the appraisal of the buyer's business competence has been inaccurate to the extent that he defaults on the construction loan, and the market value has not shown a significant increase, the seller's security is exhausted ${ }^{\mathfrak{B}}$ and the antideficiency legislation precludes a personal judgment against the buyer. ${ }^{7}$ This risk has been the cause of a number of challenges to the validity of particular agreements to subordinate. ${ }^{8}$ The challenges have occurred at two points in the transaction.

The most frequent has involved the seller's attempt, evidently upon reassessment of the wisdoin of his agreement, to disclaim the enforceability of the subordination promise. The disclaimer occurs prior to the execution of the construc-

is made upon the security of real property in which it is agreed that improvements made to the property will become a part of the security, the value of the proposed improvements may be included in the appraised value. CAI. FIN. CoDE $\$ 7156$.

The import of these provisions is that the sum of the purchase money and construction loan security will exceed the purchase price of the property, and the construction loan itself may exceed the present market value. It is the seller's desire that the actual value of the construction lien only increase proportionately to the increase in market value due to the accompanying progress in construction. In theory this may be accomplished by progressive payments.

It is common for the lender to control disbursements. They are made progressively as the work is performed. The appropriate amount is advanced to the develper to cover his actual expenses, supported by receipts, and collaborated by on site inspections by the lender. The money may also be paid directly to the contractors. But even under this system of controlled payment there is not always a direct relation between the construction expenses and a rising land value. Excavations and foundations are of negligible value when the project fails. The large increase in value is realized only when the improvements obtain a significant narket value.

The assumption that the cumulative value of the construction and purchase money liens do not exceed the value of the property is therefore inaccurate. It is fair to say that in light of the large loan permitted for construction purposes, unless the advances made by the lender are not of a significant amount, or unless the foreclosure sale occurs late in the development, the seller will enjoy a small portion of the proceeds.

See Ibid.

7 It was established in Brown v. Jensen, 41 Cal. 2d 193, 259 P.2d 425 (1953), that a nonselling junior purchase inoney encumbrancer is barred from a personal judgment against the buyer on an unsecured note. This is true even though the note has become unsecured througli exhaustion by the senior lienholder. Lucky Invest., Inc. v. Adams, 183 Cal. App. 2d 462, 7 Cal. Rptr. 57 (1961).

There has been argument that this result is not in accord with the intent of the antideficiency judgment legislation. See Hetland, Deficiency Judgment Limitations in CaliforniaA New Judicial Approach, 51 CALIF. L. Rev. 1, 7-12 (1963). Even if a personal judgment is obtainable against the buyer, its practical value is questionable. Ordinarily a corporation is formed for the purpose of the development. The judgment would be against this corporation, the assets of which had been depleted by the failure of the project. If the court were willing to "pierce the corporate veil," the buyer would more likely tlian not have disposed of his attachable assets.

8 There is no doubt that the statutory priorities may be altered by agreement. Section 2934 of the Civil Code authorizes the recordation of an instrument by which a mortagage, deed of trust, lien upon or interest in real property is subordinated or waived as to priority, and provides that recordation is constructive notice of the subordination.

The courts had recognized the right prior to the legislature's enactment. Machado $v$. Bank of Italy, 67 Cal. App. 769, 228 P. 369 (1924); International Mort. Bank v. Eaton, 39 Cal. App. 39, 177 P. 880 (1918).

Prior to 1954 there was no decision challenging the enforceability of a particular subordination agreement. Since 1954 the litigation has increased substantially. See notes 10, 16, $18,23,34$, infra. No case has gone beyond the district courts of appeal. 
tion loan, when the agreement to subordinate is still executory. ${ }^{9}$ The context has been a suit by the buyer for specific performance.

The second challenge occurs at the executed stage, when the construction loan has been issued to the buyer. The seller seeks a declaration that the subordination was not effective and that he holds the senior lien on the property. The direct cause of the second challenge has been foreclosure proceedings by the construction lender. ${ }^{10}$

Subordination has received sparse treatment by legal writers, ${ }^{11}$ and the cases are not numerous. The law that does exist has evolved almost entirely since 1954, and the opinions indicate that an "equitable" result has often been more important than the reasouning by which that result was achieved. ${ }^{12}$ In a series of consistent efforts to relieve the seller from a disastrous bargain, the cases have cast serious doubt upon the efficacy of the subordination procedure..$^{13}$

This Comment will examine the significant decisions and derive from them a framework within whicl the manifested pitfalls may be at least partially avoided. First the discussion will focus on the problems which arise at the executory stage when the buyer attempts to enforce the contract to convey. The second part deals with the contest over priority at the executed stage between the seller and construction lender, when one has foreclosed..$^{14}$

${ }^{9}$ Often the seller will promise in the deed of trust that when the buyer encumbers the property with the hen of a construction loan, this hen will automatically be semior to the purchase money instrument without further act on the part of the seller. This procedure is referred to as "automatic" subordination. See CaLIF. C.E.B., CalIForNIA LaNd SEcurity AND Deveropacent 123-40 (1960). If the agreement is challenged by the seller, usually by a refusal to execute a deed, before the construction loan has been obtained, the challenge is said to have occured at the executory stage.

Alternatively the seller may promise to execute another instrument at a future date subordinating his lien to a designated lien. Contracts to agree in the future may be a pitfall. If an essential element is reserved for future agreement, the promise can give rise to no legal obligation until the future agreement has been executed. Ablett v. Clauson, $43 \mathrm{Cal}$. $2 \mathrm{~d}$ 280, 284, 272 P.2d 753, 756 (1954). The problem of certainty, which is the primary thrust of the challenge at the executory stage, is discussed in detail subsequently. See text accompanying notes $15-45$ infra.

10 Spaziani v. Millar, 215 A.C.A. 757, 30 Cal. Rptr. 658 (1963) ; Collins v. Home Sav. \& Loan Ass'n, 205 Cal. App. 2d 86, 22 Cal. Rptr. 817 (1962). These cases are discussed extensively in regard to the problem of conditional subordination. See text accompanying notes 44-65 infra.

11 The most exhaustive discussion may be found in CalfF. C.E.B., CaLtFornia LAND Security and Developament 123-40 (1960). Also of some value are 1 GlenN, Mortgages $\S 50.3$ (1943); Ogden, Calmornia Real Property Law $\$ 17.30$ (1956); Osborne, Mortgages $\S 212$ (1951); 1 Witkm, Sumarary of Calmfornia Law 712 (1960).

13 See note 42 infra.

13 See cases cited note 16 infra. In the preparation of this Comment, an effort was made to obtain the opinions of those who use the subordination agreement. Discussion with escrow companies, real estate brokers, savings and loan companies, and title insurance companies yielded one common characteristic: confusion as to whether the benefits of the subordination process are worth the doubts as to the legal effect of the agreement. All are generally aware of the litigation, but concerned because they are unable to derive a consistent pattern as a guideline to the proper procedures.

14 At this point it is necessary to settle on the terminology which is to be used in describing the parties and the transaction. The holder of the purchase money security is the "seller." He agrees to subordinate his lien in an agreement with the "buyer," the developer of the property. The buyer negotiates a loan from the "construction lender" or "lender," which loan has priority over the purchase money security by virtue of the subordination agreement. The construction lien is the "subordmating lien," and the purchasing money lien is the "subordinated lien." This terminology will be used throughout. 


\section{ENFORCEMENT OF THE EXECUTORY AGREEMENT}

A contract may not be specifically enforced unless its terms are complete and certain $;^{15}$ but it is not clear when these conditions are satisfied. Yet the automatic subordination agreement is necessarily incomplete, because it is drawn very early in the negotiations between the buyer and seller, at a time when the exact terms of the construction loan are incapable of precise determination.

The critical problem for the courts is to determine the requisite specificity for enforcement. The majority of opimions have required that the subordinating loan be described with great detail. ${ }^{16}$ Failure to do so has meant that the entire contract was unenforceable. ${ }^{17}$ Clearly, failure to specify the maximum amount of the loan is significant. ${ }^{18}$ Enforcement has also been denied for failure to state the imterest rate, ${ }^{19}$ mode of repayment, ${ }^{20}$ and amount of monthly payments. ${ }^{21}$ Identity of the construction lender has not appeared critical.

The strict judicial attitude has suppressed the use of the automatic subordination clause. ${ }^{22}$ The alniost unanimous refusal to enforce the promise has created an uncertainty about the efficacy of the procedure. The high degree of specificity required places the buyer in a difficult position of needing the promise to subordinate in order to justify further expenditures such as engineering studies and title search, that ultimately determine the election to exercise his option to purchase. However, by securing the relatively incomplete promise to subordinate, he jeopardizes the entire transaction.

The clear impracticality of the substantial requirements for subordination raise questions as to the real intent of the courts. The degree of certainty required should insure that the seller does not assume a substantially greater risk than that originally anticipated. The buyer should be restricted to terms of the loan which

15 Ablett v. Clauson, 43 Cal. 2d 280, 272 P.2d 753 (1954) (option for renewal of lease "upon terms to be then agreed upon"); Klein v. Markarian, 175 Cal. 37, 165 Pac. 3 (1917) (option to buy land, fails to state amount of yearly payments); Alaimo v. Tsunoda, 215 A.C.A. 94, 29 Cal. Rptr. 806 (1963) (listing agreement failing to state price) ; Bonk v. Boyajian, 128 Cal. App. 2d 153, 274 P.2d 948 (1954) (option to purchase, montlly payments on the balance due to be agreed upon at the time of the purchase); Burgess v. Rodom, 121 Cal. App. 2d 71, 262 P.2d 335 (1953) (contract to purcliasc, fixed payments to be macle upon terms of subsequent mortgage).

16 Wright v. Fred Heyden Indust., ...... Cal. App. 2d ......, 6 Cal. Rptr. 392 (1960) (hearing granted, dismissed by stipulation of the parties) (failure to specify maximum amount and manner of payment in subordination clause); Kessler v. Sapp, 169 Cal. App. 2d 818, 338 P.2d 1035 (1959) (amount of future loan not stated) ; Roven v. Miller, 168 Cal. App. 2d 391, 335 P.2d 1035 (1959) (amount of future loan not stated); Gould v. Callan, 127 Cal. App. 2d 1, 273 P.2d 93 (1954) (maximum amount and mode of repayment not specified).

17 The agreement to subordinate is a material element of the agreement to convey. If it is unenforceable, the entire transaction is therefore unenforceable. In the majority of cases the buyer would no longer care to have the contract enforced if the subordination were not available. But see Roven v. Miller, supra note 16, where the buyer attempted to cure the defect by waiving the subordination agreement.

18 Kessler v. Sapp, 169 Cal. App. 2d 818, 338 P.2d 34 (1959).

19 Wright v. Fred Heyden Indus., ...... Cal. App. 2d......, 6 Cal. Rptr. 392 (1960); Gould v. Callan, 127 Cal. App. 2d 1, 273 P.2d 93 (1954).

20 Kessler v. Sapp, 169 Cal. App. 2d 818, 338 P.2d 34 (1959).

21 Ibid.

22 See cases cited at notes 13,16 supra. 
would limit the amount borrowed to the difference between the estimated value of the land with improvements, and the amount of the seller's lien. Further, the principal and interest should not fall due prior to the anticipated return of the investment. An agreement with substantially less certainty than those held unenforceable would provide these safeguards, and the transaction would not be unduly complicated. This leads to the conclusion that the inherent unfairness of the particular transactions concerned the courts more than the single question of certainty of the subordination agreement. ${ }^{23}$ This conclusion is supported by two 1963 second district opinions.

In Simmons v. Dryer ${ }^{24}$ subordination of the seller's purchase money deed of trust to a purchase money deed of trust im favor of a third party lender was upheld. Only the amount of the subordinating loan, 13,000 dollars, was specified. The previous authorities ${ }^{25}$ were distinguished on the basis that in the present agreement there was no failure "to agree upon an essential term." ${ }^{26}$ There was nothing unreasonable in the latitude afforded the buyer because it was to the advantage of both parties to obtain favorable terms. 27

The distinction of the previous cases is not convincing. First, it is always to the advantage of both parties to obtain favorable terms. Second, there was no provision for mode of repayment. In Gould $v$. Callan ${ }^{28}$ failure to make such provisions contributed to the unenforceability. Fmally, there was a glaring omission of Kessler v. Sapp, ${ }^{29}$ a previous decision of the same court. In Kessler the failure to establish the rate of interest, the amount of monthly payments, and the period of the debt was held to be such a radical uncertainty that not only was specific enforcement unavailable, but also an action for damages. ${ }^{30} \mathrm{~A}$ convincing distinction is nonetheless available. Simmons involved subordination to a third party purchase-money security, rather than to a construction loan. This difference is significant.

When the seller subordinates to other purchase money security, he receives the principal of the subordinating loan as a cash payment on the purchase price. The lender therefore has presumptively loaned for less than the market value of the property, and the sum of the two liens should not exceed the purchase price. Barring deflation in value of the land, the seller's junior security will not be exhausted by the semior's foreclosure and sale. ${ }^{31}$ Conversely, in the construction loan situation, until the value of the improvements has substantially increased

23 See note 42 infra.

24216 A.C.A. 789, 31 Cal. Rptr. 199 (1963).

25 The court cited only Roven v. Miller and Gould v. Callan. Id. at 798, 31 Cal. Rptr. 205.

28 Ibid.

27 Id. at 799, 31 Cal. Rptr. at 206.

28127 Cal. App. 2d 1, 273 P.2d 93 (1954).

29169 Cal. App. 2d 818, 338 P.2d 34 (1959).

30 The personnel of the court had changed, although not entirely. Kessler was written by Shinn, J., with Wood, J. and Vallée, J. concurring. Simmons was written by Ford, J., with Shinn, $J$. and Files, $J$. concurring. This change does not explain the failure to mention $K e s s l e r$.

31 The third party lender is subject to the bar against deficiency judgments of $\$ 580 \mathrm{~b}$ of the Code of Civil Procedure when he gives the buyer a purchase money loan. Bargioni v. Hill, 59 Cal. 2d 121, 378 P.2d 97, 27 Cal. Rptr. (1963); Hetland, supra note 7, at 15-17. It should be noted that the 1963 amendment to the Code limits the bar on third party lenders to purchase money security on residential property. 
the market value, the property is overencumbered..$^{32}$ The substantially smaller risk in the purchase-inoney situation justifies a less complete subordination agreement.

By the standards of the previous cases which dealt with subordination to construction loans, the agreement in Simmons was mcomplete and uncertain. Rather than distinguish the cases on the difference in the purpose of the loans, the court chose the less convincing distinction that the agreement was certain as to fundamental terms. The court provided the missing secondary terms by honoring the discretion of the buyer, and his duty to act in good faith, until shown that this duty was breached. ${ }^{33}$ Why it selected this distinction is unclear.

It may be that the court, recognizing the inherent fairness of the bargain, did not feel it was necessary to go further and closely scrutinize the certainty problem. But it may be that the court was convinced by its own argument that in fact the agreement was sufficiently certain. Because of the alteruative ground of distinction from the previous cases, ${ }^{34}$ Simmons is not clear authority for a more realistic requirement of specificity. But when read in conjunction with a subsequent opinion by the same court, it is stronger evidence of such a trend.

In Burrow v. Timmsen ${ }^{35}$ the court was confronted with an automatic subordination agreement that specified only the maxinum amount, nuaximum interest, and maximum date of maturity. Mentioning but not distinguishing the prior decisions, ${ }^{36}$ the court reversed an order for a judgment on the pleadings for defendant seller, implying that the contract was specifically enforceable. ${ }^{37}$

The court abandoned its previous protective role in favor of an active participation in drafting the parties' contract. Emphasizing a judicial attitude which favors enforcenient of contracts, ${ }^{38}$ the court avoided problems of uncertainty by an instruction that the trial court look to what would be usual and reasonable termis in similar transactions, and to implement the agreement with these terms.

Relying on the aphorism, "That is certain which can be made certain," 30 the case was remanded to the trial court to do just that. The court was instructed to answer two questions: (1) whether the agreenient was just and reasonable, and (2) whether the agreement contained the fundamental termis required for enforceinent. If both were answered in the affirmative, the trial court was to include provisions in the decree for specific performance defining in detail the terms of the note and trust deed that would be the superior encumbrance. The court was limited to the extent that it could not alter or vary the terms of the agreement.

The narrowest interpretation of the appellate court opinion is that, as a matter

32 See note 5 supra.

33 The court relied on California Lettuce Growers, Inc. v. Union Sugar Co., 45 Cal. 2d 474,289 P.2d 785 (1955), which stated that "when a contract confers on one party a discretionary power affecting the rights of the other, a duty is imposed to exercise that discretion in good faith and in accordance with fair dealing." $I d$. at 484, 289 P.2d at 791.

34 See text accompanying notes 30-33 supra.

35223 A.C.A. 304, 35 Cal. Rptr. 668 (1963).

36 The only subordination case cited is Kessler v. Sapp, 169 Cal. App. 2d 818, 338 P.2d 34 (1959). The remainder concern the enforceability of a land contract. 223 A.C.A. at 308-09, 35 Cal. Rptr. at 671.

37 Id. at 311,35 Cal. Rptr. at 672 .

38 See King v. Stanley, 32 Cal. 2d 584, 197 P.2d 321 (1948); Martin v. Baird, 124 Cal. App. 2d 598, 269 P.2d 54 (1954).

30 Cal. Crv. Code $\$ 3538$. 
of law, the agreement is neither unjust nor uncertain. There is a strong overtone that the agreement is in fact both just and enforceable. This is a distinct departure from the requirements of earlier cases such as Kessler. ${ }^{41}$

The inconsistency is real only if the previous cases are accurate declarations of the minimum requirements for specificity, and the strictness is not attributable to an effort to achieve an equitable result. ${ }^{42}$ Burrows may be the first instance in the area of subordination where a court has said what it means. The trial court is to make an express finding of reasonableness. Only if the agreement is just is the court to determine whether the fundamental terms are present. If so, it is to fill in the details in conformity with present business practices. Simmons was consistent, but the court did not go far enough in its reasoning. The previous cases are consistent because of patent unfairness.

The question remains: What are the fundamental terms? Burrows provides a partial answer by incorporating the actual agreement in the opinion. It provides that the construction loan may not exceed a maximum amount, nor that interest exceed a maximum rate. Payment should not be made over a period in excess of thirty years, and the loan is to be from an institutional lender. The inplication is that the court considered this agreement sufficiently complete to enforce.

This agreement is an unsatisfactory prototype. First, the seller is equally, if not more, concerned with establishing a minimum period than a maximum for repayment. If the loan is subject to call within a short period, it is likely that the buyer will not have realized the return on his investment, and will be unable to meet the payment schedule. The longer the period over which payments are aunortized, the less likely is the probability of default. Further, if the payments on the construc-

40 The appellate court reversed the order granting a judgment on the pleadings. The test for a judgment on the pleadings is the same as that for a general demurrer: failure to state a cause of action. See 2 Wrtkin, Calirornia Procedure 1704 (1954). The reversal in its narrowest sense means that plaintiff did state a cause of action.

41 See Kessler v. Sapp, 169 Cal. App. 2d 818, 338 P.2d 34 (1959).

42 The unfairness in the previous cases is patent. In Gould v. Callan, 127 Cal. App. 2d 1, 273 P.2d 93 (1954), the buyer convinced Mrs. Martin, the seller, to obtain a loan for one third of the purchase price, secured by a first deed of trust on the property. Title was to pass to the buyer with this lien on the property. The remainder of the purchase price was secured by a second deed of trust in favor of Mrs. Martin. There was an agreement to subordinate this lien to a construction loan lien if obtained.

Under this agreement, Mrs. Martin would lose the rental imcome from the property. Further, it could be necessary for ler, in order to protect her interest, to expend $\$ 180,000$ (the proposed construction loan) for property which she owned outright until she had been persuaded to encumber it with the $\$ 20,000$ first loan. On the other hand the buyer was in a position where he could not lose personally. He could walk out on the second purchase money deed of trust without personal hability. CaL. Code Crv. Proc. \$ 580b. The attitude of the trial court towards the bargain was expressed: "I just can't conceive of any attorney advising his chient to go into a deal like that. It doesn't make sense to me." Reply Brief for Respondent, p.21.

In Kessler v. Sapp, 169 Cal. App. 2d 818, 338 P.2d 34 (1959), the purchase price was to be $\$ 115,000$ less the sum, if any, by which the cost of subdividing the property exceeded $\$ 15,000$. When it was determined that the subdivision costs would be $\$ 56,856.74$, the seller advised the buyer that he would not go forward with the agreement. This large cost may have motivated the court to relieve the seller from this unfair bargain.

In Roven v. Miller, 168 Cal. App. 2d 391, 335 P.2d 1035 (1959), there was an express finding of fraud by the trial court for plaintiff's nondisclosure of the fact that an eminent domain proceeding for freeway purposes was about to be commenced against the property. There was a general tone of unequal bargaining. Evidently the unfairness of the transactions concerned the courts in these cases in addition to the single problem of specificity of the subordination agreement. 
tion loan do not fall due prior to the return on the investment, it is more likely that at least part of the initial profits will be applied to the purchase money lien.

Another criticism is that the agreement contained no limitation on the amount of the lender's fees. These fees may comprise a substantial part of the payment in excess of the principal, and may be greater than the interest rates. ${ }^{43}$ Unless a restriction on fees is included, the lender may circumvent the interest restriction by complying with that restriction and charging correspondingly higlier fees.

Provision for the nature of the lender should not be a sine qua non for enforcement. The seller may wish to restrict the automatic subordination to a loan from an institutional lender. Otherwise there is no statutory requirement that the lender hold the first lien, and the necessity of subordination is removed. The consequences of the selection of a private lender are not significantly disadvantageous to the seller. The private lender may be more prone to foreclose at the first evidence of default. This possibility is weighed against the usury hinitation applicable to the private lender from which the institutional lender is exempt. 44 The nature of the lender is not of such consequence that it should be characterized as a fundamental term.

In conclusion, the duty of protection to the seller that the courts have assumed should be fulfilled when the agreement specifies the maximum amount of the loan, maximum interest, including fees, and the minimum period for repayment. ${ }^{45}$

\section{$\Pi$}

\section{ENFORCEMENT OF THE EXECUTED AGREEMENT}

In addition to the limitations on the terms of the loan, it is common to mclude in the subordination agreement a limitation on the use of the funds. Typically it is specified that the money is to be used only for construction purposes, or is not to be used for "off-site" improvements. What is the effect upon priorities (1) if

43 In Collins v. Home Sav. and Loan Ass'n, 205 Cal. App. 2d 86, 22 Cal. Rptr. 817 (1962), interest was limited by the seller to $7 \%$. While the actual rate on the construction loan was $6 \mathrm{I} / 2 \%$, the lender charged $13 \mathrm{I} / 2$ "points" or "fees" for the loan. The total payment in excess of the principal was therefore $20 \%$ of the $\$ 2,134,860$ loan, or $\$ 426,972$.

44 The legislature bas not chosen to apply usury laws to institutional lenders. The state Constitution provides that no interest rate shall exceed $10 \%$. CAL. Const. art. $20 \S 22$. But the section then qualifies this provision to make it inapplicable to institutional lenders, and authorizes the legislature to prescribe the maximum rates as it sees fit. This it has not done.

45 It should be empliasized that these suggested provisions are only those necessary to satisfy the certainty requirement. There are others the seller nay feel it wise to include in order to further protect his lien. A provision that the lender progressively distribute the funds would guard against misuse and overencumbrance. See note 5 sicpra. There slould be a time limitation on the period during which the buyer can exercise his option to subordinate the seller's lien. A probibition against a contracted for prepayment penalty would prevent the payment of this penalty by the seller were he to choose to buy in on the construction loan lien. See generally Cominent, Secured Real Estate Loan Prepayment and the Prepayment Penalty, 51 Carm. L. Rev. 923 (1963). Finally, the seller inay wish to specifically exclude the possibility of a "take out" procedure, whereby the construction loan is converted to a purchase-money lien on each lot, the obligor being the lot purchaser.

The buyer may wish to include a provision that the seller agrees to execute a written document at the time the construction loan is executed declaring that the loan complies with the conditions set forth in the original subordination agreement. The lender, as well as the buyer and seller, could be a party to this subsequent instrument. The result would be to prevent many of the problems which arise from conditional subordination. See text accompanying notes $46-62$ infra. 
the buyer obtains a loan that does not conform to the specified terms, or (2) if the buyer uses the funds for purposes other than those designated in the agreement?

These questions are not easily answered. It may be that non-compliance with either type of restriction has no effect on priority. The subordination is effective and the seller has as the only remedy an action for damages against the buyer. This solution involves obvious inequities because the question usually will arise only when the buyer is insolvent and the security is exhausted. ${ }^{46}$

A more palatable alternative is that the specified terms are conditions of subordination, and subordination occurs only upon fulfillment. Is this also true of the use requirement? Perhaps the use requirement is a promise between the seller and buyer, the breach of which has no effect on the lender's rights. Characterization at this point in the discussion would be to state a conclusion without the reason, and therefore should be postponed subject to an intervening examination of the relevant case law and policy considerations.

In Collins v. Home Sav. \& Loan Assoc., ${ }^{47}$ the seller sought a declaratory judgment and an accounting after the lender bad exercised his power of sale and purchased at the sale. ${ }^{48}$ The lender had asserted priority on the basis of a subordination agreement between the seller and defaulting buyer. The agreement contained specific limitations on the terms of the loan, and the further limitation that the funds were to be used only for constructing on each lot a dwelling house with usual appurtenances and improvements. ${ }^{49}$ The seller sought a declaration that the agreement did not alter the priorities because the terms of the loan did not comply with the required terms, and the buyer had misused the funds. ${ }^{50}$ The trial court found that the lender had disbursed the funds with knowledge that the buyer would use them for unauthorized purposes, and charged a "fee" which exceeded the stipulated interest rate. ${ }^{51}$ Judgment was for the seller for the principal amount of the purchase money note, plus interest. The district court of appeal affirmed.

In Spaziani v. Millar, ${ }^{52}$ plaintiff seller brought an action for damages against the buyer, escrow holder, and lender. Plaintiff lad agreed to sell her property, taking a purchase money deed of trust, to be subordinated in the future to a "construction loan to follow." The buyer filed a loan application with defendant lender. The lender instructed the escrow holder that the loan would be issued when a policy of title insurance had been received showing title to the property vested in

46 See note 43 supra.

47205 Cal. App. 2d 86, 22 Cal. Rptr. 817 (1962).

48 By the time of judgment, the lender had completed the project and conveyed to individual home owners.

40 The provisions of the agreement nay be summarized as follows: (1) the loan was not to exceed $80 \%$ of the value of the lots. It was to be used for the purpose of constructing a dwelling house on each lot with usual appurtenances and lot improvements; (2) interest was not to exceed $7 \%$ per annum; and (3) sellers were to release each lot from the trust deed upon payment of $\$ 2000$ per lot.

50 Approximately $\$ 80,000$ was apphed to the purchase price, $\$ 86,940$ was immediately apphied by the lender to pay itself a portion of the total points it was charging. Approximately $\$ 160,000$ was paid for supervisory services to an alter ego of the borrower.

51 In addition to $6 \mathrm{x} / 2 \%$ interest the lender charged $13 \% 2 \%$ "points," or "fees." The loan was $\$ 2,134,860$. The lender had a total return therefore of $20 \%$ of the principal, or $\$ 426,972$. The court never states that in fact "fees" are included in interest for the purpose of determining whether the rate is in excess of the maximum authorized in the agreement. It is reasonably clear that fees should not be included, but instead should be provided for separately by the contracting parties. If the $7 \%$ is constrned to include fees, it is an unreasonable limitation on the buyer.

52215 A.C.A. 757,30 Cal. Rptr. 658 (1963). 
the buyer. The lender was aware the escrow instructions stated that the loan was to be for construction, whereas the loan applied for was for "purchase assistance." Upon inquiry to the escrow agent, the lender was informed that the construction loan requirement referred to another obligation to be placed on another portion of the property. This satisfied the lender. The escrow agent closed the escrow, recorded the first deed of trust in favor of the loan company, and the second in favor of the seller. After several payments the buyer defaulted on the first trust deed, and the lender initiated a trustee's sale which was stayed pending the outcome of the seller's action. ${ }^{53}$ The trial court rendered a decision against plaintiff and in favor of the buyer, escrow loolder and lender. On appeal the judgnient for the buyer and lender was affirmed; the nonsuit in favor of the escrow holder was reversed.

Collins and Spaziani do more to increase than decrease the confusion over the relative priorities of the lender and seller when the buyer defaults on either security. Nevertheless they are the only case law. The questions raised at the beginning of this section nust be examined in light of these opinions.

\section{A. Non-compliance With the Specified Loan Terms}

What if the buyer obtains a loan that does not conform with the specified terms? In Collins there is language that the terms are conditions of subordination. ${ }^{54}$ Non-compliance therefore results in retention of priority by the seller. ${ }^{55}$ While it is clear that this is the proper result, the court offered neither reasoning nor relevant authority to support the result.

The question was discharged with a brief sentence: "An agreenient to subordinate a mortgage (or trust deed) may be made subject to particular terms or conditions, the validity of such conditional subordination agreements being recognized in California." 56 The authority the court cites is Bank of America v. Hirsch Mercantile $\mathrm{Co}_{.}{ }^{57}$ a case that concerned the subordination of a deed of trust to a subsequent lease on the property. The parties to the agreement were the trust deed holder and the lessee. ${ }^{58}$ This case stands only for the proposition that the con-

53 Id. at 766, 30 Cal. Rptr. at 663 . It should be noted that both Collins and Spaziani involved trustee's sales under the power by the construction lender. Therefore the question of res judicata was not relevant in the subsequent actions. If the foreclosing party proceeds by judicial sale in order to avoid the anti-deficiency bar of $\$ 580 \mathrm{~d}$, the question of priority should be raised by the seller at the foreclosure proceeding, assuming he is named as a junior lienholder. It may be that a subsequent attack at the priorities is barred by res judicata.

54205 Cal. App. 2d at 95, 22 Cal. Rptr. at 823.

55 This is inferred from the trial court's statement that it is more equitable to grant a recovery in daunages for the amount of the unpaid principal plus interest, instead of setting aside the trust deed sales and involving the subsequent lot purchasers. It is questionable whether the court mcans "damages," since the action was one for declaratory relief and an accounting. Damages for fraud were pleaded, but the trial court found that there was no fraud. $I d$. at $89,22 \mathrm{Cal}$. Rptr. at 818 .

It is conceptually better to characterize the seller's recovery as based on a senior priority. Due to the unique circumstances that the property was subdivided subsequent to the sale under the power, it was more equitable to give the seller a lien against the proceeds of the sale as a substitute for his lien against the property. This protects the subsequent purchasers.

5686 Cal. App. 2d 86, 95, 22 Cal. Rptr. 817, 822-23 (1962).

5764 Cal. App. 175, 148 P.2d 110 (1944).

58 At the time lessee negotiated the lease, the defendant henholder beld a deed of trust on the property. In a separate agreement, defendant agreed to subordinate bis deed of trust to the lease for ten years. When defendant foreclosed prior to the expiration of the ten years, lessee's right to continue in possession was affirmed by the court. 
ditions are binding on the parties to the agreement. The question in Collins is whether the conditions are binding on the lender, who is not a party to the agreement. Do these conditions control the priority between him and the seller? Bank of America v. Hirsch is not in point.

The failure of the court to support with reasoning the conclusion that the subordination is conditional is unfortunate; Spaziani, in dictum, suggests an opposite result. The seller in Spaziani presented the argument, based on Collins, that subordmation is not effective unless the loan complies with the subordination terms. The court rejected this argument because "the purpose for which the first loan had been made bore no relationship to its priority." 59 It was not necessary for the court to reach this question because plaintiff's claim was for damages. The conclusion is correct that the lender is under no duty to the seller. The lender is not a party to the agreement. The seller chose an unfortunate remedy and the court was correct in denying it.

It is not conceptually difficult to require that the construction loan be consistent with the specified terms of the agreement, at the risk that the lender will in fact hold a jumior lien. The seller has expressly specified a lien to which he will subordinate. The lender should be aware of the restrictions, and will have obtained title insurance on his priority. The burden on the seller would be disproportionate to the burden on the lender if the subordination is effective without compliance.

Having reached this conclusion, how may Spaziani and Collins be reconciled? Two points distinguish the cases. First, since Spaziani was an action for damages against the lender, it was not necessary to reach the question of lien priority and the statements are therefore dictum. Second, the loan was accepted and recorded with senior priority by an agent of the seller, the escrow holder.

This agent was vested with the authority to record the seller's deed of trust as a second lien. This authority was manifested to the lender by the seller. The court proceeds under the assumption that when the agent accepted the proceeds of the loan in escrow, and recorded the trust deeds with the designated priority, the seller was bound by the act of his agent. It is argnable that only within these unique circumstances did the court intend that the conditions of the agreement be ineffective in barring the subordination. Absent the seller's agent, the fulfillment is a condition precedent to subordination.

While the agency argument resolves the conflicting results of Collins and Spaziani, it should be noted that the court indulges in an incorrect application of agency theory under the facts, and Spaziani should not be rehed upon to protect the lender in similar circumstances. It is true that the escrow agent was an agent of the seller, but his express authority was clearly defined in the escrow instructions: the first deed of trust was to secure a construction loan. Since the agent had no express authority to accept the purcliase assistance loan, the seller would only be bound if he had created an apparent authority in the agent. ${ }^{60}$ Under the facts this is a difficult, if not impossible, argument because the lender had actual knowledge of the instruction. The statements of the agent in response to the lender's inquiry into the inconsistency between the authorized loan and the actual loan do not bind the seller. The apparent authority must rest on an appearance created by the principal. The acts and statements of an agent cannot create an

59215 A.C.A. 757, 770, 30 Cal. Rptr. 658, 655 (1963).

60 Cal. Crv. Code $\S \S 2317,2318,2334$; Dickens v. Bunker, 169 Cal. App. 2d 383, 337 P.2d 489 (1959). 
apparent authority. ${ }^{61}$ The lender therefore relied on the statements of the agent at his own risk:

If the conditional subordination theory of Collins is accepted, the opposite result should be reached in subsequent litigation under the Spaziani facts. Unless the instructions as to the limitations on the escrow agent's authority are not disclosed, the lender is under a duty to ascertain for himself whether the loan in fact complies with the conditions of subordmation. The question will be whether pubhication in the escrow instructions is sufficient to limit the authority of the agent, absent actual knowledge of the limitation. ${ }^{62}$

\section{B. Non-compliance With Use Requirements}

The conclusion was reached in the previous section that if the terms of the construction loan deviate substantially from those prescribed by the seller, the subordination will not occur. ${ }^{63}$ Does the same result follow when the loan money is not applied to the purpose designated in the construction loan?

In Collins $^{\text {Gt }}$ the court condemns with equal fervor the excessive loan expenses and the disbursement of the loan funds despite the lender's knowledge that the buyer intended to use the money for non-construction expenses. But here, as before, the court's conclusionary language provides little assistance. It is not clear whether the seller's recovery was predicated, at least in part, on the misapplication of the funds alone, quite apart from the construction lender's actual knowledge of the intended misappropriation.

It is argnable that the court did not consider the use of the loan proceeds a condition of subordination. If priority is dependent on proper use, the construction lender should hold seniority as to the amount correctly used for construction purposes; the amounts advanced should be considered severable. The priority of the construction loan lien vests at the time the funds are applied to the construction purpose. Therefore, if the seller is to recover the entire amount of his purchase money lien from the construction lender, as he did in Collins, the misappropriated funds must exceed the balance due on the purchase price.

Unfortunately, for academic purposes, this was the case in Collins. The misapplied funds exceeded the seller's lien, and there was no need to apportion. The question remains whether the failure to discuss the relative amounts of the hens indicates that the use requirement is not a condition of subordination, or alternatively that the Collins court did not face the problem.

61 Cal. Civ. Code \$2317; Torrance Nat. Bank v. Enesco Fed. Credit Union, 134 Cal. App. 2d 316, 285 P.2d 737 (1955); Hill v. Citizens Nat. T. \& S. Bank, 9 Cal. 2d 172, 69 P.2d 853 (1937).

62 Spaziani signals a warning to the escrow agent. Failure to obey the instructions of his principal and exercise reasonable skill and ordinary diligence $i \mathrm{~h}$ his employment results in a liability for any loss occasioned by the breach of duty. Rianda v. San Benito Title Guar. Co., 35 Cal. 2d 170, 217 P.2d 25 (1950); Jones v. Title Guar. \& Trust Co., 178 Cal. 375, 173 P. 568 (1918). In Spaziani, a non-suit in favor of the escrow agent was reversed and the case was remanded for determination of the question of his negligence. If the court had correctly resolved the question of whether the act of the agent bound the seller to a junior priority, there would have been an action for only nominal damages against the escrow, because the breach of duty had not resulted in a loss of priority. In a situation where the agent's negligent act does bind the seller, Spaziani indicates a liability of the escrow agent for damages.

63 See text acconipanying notes 43-62 supra.

64 Collins v. Home Sav. \& Loan Ass'n, 205 Cal. App. 2d 86, 22 Cal. Rptr. 817 (1962). 
Collins leaves future courts, confronted with a similar problem, relatively free from precedent. Rather than resort to conclusionary language to justify an equitable result, resort should be to a fresh examination of what the primary rights are. Assuming that the lender is unaware of the intended misuse, the question is one of allocation of risk: if the buyer intends to defraud the parties, between the seller and the lender who should suffer the loss? Three considerations are important: (1) who can best afford the loss; (2) who is in the best position to prevent the misuse; and (3) what will be the effect on subsequent transactions.

Financially, the lender is likely to be in the best position to absorb the loss. He may provide for such a contingency by his profit and loss estimate. Further, when the lender holds the junior lien, he suffers a less severe loss than the seller. The lender is not barred by the deficiency judgment prohibition of Section 580b of the Code of Civil Procedure, because he does not hold a purchase money lien; the seller is barred. ${ }^{65}$ Therefore the lender may recover personally against the buyer, if he is solvent.

If the seller does retain his priority, and the lender purchases at the seller's foreclosure, the lender is in the position of owning the property for a price presumably less than the market value; the proceeds paid on the loan are at least partially recouped through the improvements made, if any.

On the other hand, allocating the risk to the lender may have a substantial effect on his available capital. Section 7255 of the Financial Code provides that the savings and loan commissioner may require each association to establisl and maintain a loss reserve for the amount by which the book value of any asset exceeds the commissioner's appraisal of the asset. It is arguable that by analogy, if the loan is not in fact made on the security of the first lien, or if the assumed priority is subject to divestment by the buyer's misapplication, the commissioner could require a loss reserve equivalent to the value of the lender's lien. This would have a detrimental effect on the lender's operation by removing a portion of his funds from circulation.

Another consideration is that the lender is in the best position to prevent the contingency from occurring. Cash payments on the loan should be made only upon presentation of evidence, in the form of receipts and on-site inspections, that the expenses lave been imcurred. In theory this prevents misuse. ${ }^{66}$ While it is a greater burden on the lender to impose this duty of supervision, this is balanced against the position of the seller; it is impossible for him to control the use.

The conclusion is that the lender's greater ability to absorb the loss, the probability that his loss will be substantially less, and his position of relative control over the use of the funds should place the risk of misappropriation on him. He holds the senior lien only to the extent the disbursed funds are applied to the designated purpose.

The allocation of loss for misuse to the lender should be significant only to the extent that it will force the parties to provide for the relevant contingencies by contract. A major cause of the nianifold problems whicl have arisen has been poor draftsnianship of the subordination agreements. Consequently the courts have been confronted with agreements which madequately define the parties' 
rights. In facing the equities of the particular situation, Collins contributes a precedent which disfavors the lender.

But this law is only suppletive. There is no bar to contractual allocation of responsibility for the misappropriation; the relative rights should be set forth with specificity. A procedure has developed whereby at the time of execution of the construction loan, an agreement is signed by the three parties concerned, defining the loans and setting forth the priorities. Provision for this agreement may be made in the "automatic" clause. This procedure should be expanded to include provision for the contingencies which might arise after subordination. When this is the case, Collins and Spaziani are significant only in a historical sense.

\section{CONCLUSION}

The subordination agreement will continue to be a practical necessity of real estate financing as long as the requirement exists that the institutional lender hold the first lien on the property. Despite its importance and relative simplicity, reliance on subordination procedure lias been significantly weakened by judicial opinions. The excessively formal requirements for an enforceable automatic agreement, with the possible consequence that the entire transaction would be unenforceable, made their use extremely hazardous. The opimions which faced the question of priorities at the executed stage stated the conclusions unaccompanied by reasons for the result, relying instead on inherent faimess.

Fortunately, Burrows indicates a more realistic trend in the area of automatic subordination. Its primary contribution is that it establishes a prototype for an enforceable subordination agreement. With the suggested improvements, there is no reason why a future court should find unenforceable an agreement which conforms.

Collins provides a warning that the parties should settle the problems at the contractual stage. Prior to Burrows, the seller could readily avoid the agreement at any time up to the execution of the loan, and perhaps afterward. With the enforceability established, and this exit closed, his best alternative is a clear declaration of rights in a three party agreement at the time of subordination. Previous failure to provide for the contingency of misappropriation has thrust the problem on the courts. The three party agreement returns it to the hands of the draftsmen. 